\title{
Happiness Effect of the Social Security Participation in Urban and Rural China: An Empirical Analysis Based on CGSS 2015 Data
}

\author{
Jiao Zhang ${ }^{1, \text { a }}$, Jianding Ding ${ }^{1, b}$ \\ ${ }^{1}$ School of Sociology,Huazhong University of Science and Technology, 1037 Luoyu Road, Wuhan, China \\ a sanniozhang@163.com, bdjding1965@163.com \\ *corresponding author
}

Keywords: happiness effect, social security participation, endowment insurance, medical insurance

\begin{abstract}
Based on the Chinese General Social Survey (CGSS) 2015 and the ordered logit regression analysis, this study empirically estimates the happiness effect of the social security participation in urban and rural China. The results are as follows: (1) Social security participation has a significant impact on improving the subjective sense of happiness of the residents, the more the benefits they enjoy, the happier they feel. (2) The happiness effect of the social security participation on rural households is greater than that of the urban households, and the former can get more enjoyment from the social security system. (3) The happiness impact of the medical insurance participation is greater than that of the endowment insurance, and the relationship between the endowment insurance participation and the residents' happiness is not significant. Overall, the relationship between the social security participation and the happiness of urban and rural residents can provide a reference for the construction of the social security system in contemporary China.
\end{abstract}

\section{Introduction}

The social security system is one of the basic social frameworks to ensure and improve the livelihood of the people, to maintain social justice and social stability, and to regulate the distribution of income and promote economic development. As the core issue of the livelihood and the public finance, the goal of the social security serves to the ultimate goal of the government and the institutional arrangements-to improve the well-being of the people. Over the past three decades of Reform and Opening-up, China has made remarkable achievements in economic field, and the social security system covering the urban and rural areas has also basically taken shape. However, according to the World Happiness Report (2018) released by the United Nations, the happiness index of Chinese citizens ranked only 86 in 156 countries (districts). It indicates that the happiness of Chinese residents does not seem to be promoted with the improvement of the social security system synchronously, and the goal of this study is to measure the impact of the social security system on happiness of urban and rural households in China.

\section{Study Review}

One of the focuses of the existing researches on happiness is to explore the factors that affect well-being $^{[1]}$. A pioneering paper published in 1974 on income and happiness aroused the interest of economists in the study of happiness and since then, both theoretical and empirical analysis on happiness have developed rapidly ${ }^{[2]}$. Scholars have made progress on exploring the relationship between income and happiness and the relevance between employment, government spending, ecological environment and happiness are also under constant study.

It is controversial on the topic that to what extent the social security affects the happiness of citizens according to the existing studies. One review study on happiness pointed out that changes in government welfare policies have had an important impact on public well-being ${ }^{[3]}$. While another research found that there had no significant relationship between welfare spending and life 
satisfaction $^{[4]}$. It can be seen that the study of the happiness effect of the social security system is not clear in different regions and different groups of people and this subject requires more empirical evidence to analyze.

\section{Research Hypotheses and Data Variables}

\subsection{Research Hypotheses}

According to the existing literature, participation in the social security system means the increase in disposable income of residents. Also, social security system plays the role of a social safety net and provides protection for citizens' basic lives and normal development and gives people a sense of stability. In addition, as a means of redistribution of national income, social security plays a considerable role in regulating the sense of unfairness that caused by income distribution gaps. Thus, hypothesis1 is presented:

Hypothesis1.The more social security benefits the residents enjoy, the more subjective sense of happiness they feel.

The dual household registration system in China causes the difference of participation rate and the welfare level that citizens could share in urban and rural areas ${ }^{[5]}$. The mental attitudes and values of urban and rural households are also different because of their different sense of identity aroused by the segmented reality. There are many disadvantaged groups among rural residents and their income is not as stable as that of urban residents. The participation of social security will make the rural households get a stronger sense of safety for they are under protection. Correspondingly, the impact on the residents of urban areas is relatively weak. Thus, hypothesis2 is presented:

Hypothesis2. Social security has less impact on residents of urban areas than that on rural households, which means that the social security has a stronger effect on rural residents.

\subsection{Dependent variable}

The data used in this paper are all from China General Social Survey project (2015).The project aims to systematically monitor the changing relationship between social structure and quality of life in both urban and rural China. The variable happiness is the dependent variable for this study and the value is derived from the answer given by the question A36 in the CGSS questionnaire, "Generally, do you think your life is happy?" and the answer is divided into "very unhappy, less happy, not clearly, happy, and very happy."

\subsection{Independent variable}

Basic social security is the core independent variable. It comes from question A61, "The following social security programs you are currently participating in". The items are set as "participate in Urban Basic Medical Insurance/New Rural Cooperative Medical Insurance" and "participate in Urban/Rural Basic Pension Insurance". It is coded as 1 if the answer is yes, or coded as 0 (which means that the interviewee did not participate in the insurance)

On the basis of this, the participating behaviours into the following four variables: residents who participated in no basic social security program, residents who only participate in medical insurance, residents who only participate in pension insurance, and residents who have participated in both two policy-based social insurance programs.

\subsection{Control variables}

In order to enhance the persuasiveness of the quantitative analysis, other factors that may affect the subjective sense of happiness need to be fully considered. With reference to the existing theories and research results, this study selects the factors below as control variables: gender, age, relative income, health status, education level, and political status. 


\section{Empirical Results and Analysis}

\subsection{Research Methods}

Stata is the solution for data science needs and the data used in this paper is analyzed by stata14.0. For the dependent variable is an ordered variable, ordered logistic regression is adopted to analyze the happiness of the residents.

\subsection{Descriptive Statistical Analysis}

Table1 illustrates the subjective sense of happiness in China and shows the urban-rural difference of it. It shows that citizens generally feel happy about their life, accounted for $77.74 \%$ in the total sample and $17.64 \%$ of residents feel very happy. The proportion of residents who feel unhappy was small. In terms of household registration, the proportion of rural residents who feel happy accounted for $76.18 \%$ and the proportion of urban residents accounted for $80.46 \%$. The happiness index of the residents of urban areas is slightly higher than that of the rural household.

Table 1 Happiness and urban-rural difference

\begin{tabular}{|c|c|c|c|}
\hline \multirow{2}{*}{$\begin{array}{c}\text { The Subjective } \\
\text { Sense of Happiness }\end{array}$} & Nationwide & Rural Household & Urban Household \\
\cline { 2 - 4 } & $1.26 \%$ & $1.35 \%$ & $1.11 \%$ \\
\hline Very unhappy & $6.25 \%$ & $7.11 \%$ & $4.76 \%$ \\
\hline Less happy & $14.74 \%$ & $15.35 \%$ & $13.67 \%$ \\
\hline Not clearly & $60.10 \%$ & $59.37 \%$ & $61.36 \%$ \\
\hline Happy & $17.64 \%$ & $16.81 \%$ & $19.10 \%$ \\
\hline Very happy & 10632 & 6747 & 3885 \\
\hline N & Stanc & \\
\hline
\end{tabular}

Table 2 illustrates the descriptive statistical feature of the participation. $67.96 \%$ of the interviewees participate in two social insurance programs, and about $7 \%$ of the residents do not participate in any policy-based social insurance. Compared with residents who only participate in pension insurance, the proportion of residents who only participate in medical insurance is significantly higher and about 12 times than the former. In the sub-samples, the proportion of participation in both of policy-based social insurance has obvious difference in rural households and urban households, which accounts for $75.47 \%$ and $63.63 \%$ respectively. Apart from this, the proportion of urban households who have not participated in any basic social insurance is slightly larger than that of rural households. And the proportion of rural households who only participate in medical insurance is much larger than that of urban households, while urban households who only involved in pension insurance is much higher than that of the rural residents.

Table 2 Participation type and urban-rural difference

\begin{tabular}{|c|c|c|c|}
\hline \multirow{2}{*}{ Participation Type } & \multicolumn{3}{|c|}{ Urban-rural Difference } \\
\hline & Nationwide & $\begin{array}{c}\text { Rural } \\
\text { Household }\end{array}$ & $\begin{array}{c}\text { Urban } \\
\text { Household }\end{array}$ \\
\hline Do not participate in any basic social insurance & $\begin{array}{c}724 \\
(6.81 \%)\end{array}$ & $\begin{array}{c}450 \\
(6.67 \%)\end{array}$ & $\begin{array}{c}274 \\
(7.05 \%)\end{array}$ \\
\hline Only involved in medical insurance & 2476 & 1863 & 613 \\
$(23.29 \%)$ & $(27.61 \%)$ & $(15.78 \%)$ \\
\hline Only involved in pension insurance & 207 & 141 & 66 \\
$(1.95 \%)$ & $(2.09 \%)$ & $(1.70 \%)$ \\
\hline Participate in two social insurance programs & 7225 & 4293 & 2932 \\
& $(67.96 \%)$ & $(63.63 \%)$ & $(75.47 \%)$ \\
\hline \multirow{2}{*}{$\mathrm{N}$} & 11009 & 6747 & 3885 \\
\hline
\end{tabular}


Table 3 illustrates the code number of the variables that selected in the study. Also, the numerical characteristics like mean, stdev, min and max of the variables are showed in this table.

Table 3 Numerical characteristics and code number of variables

\begin{tabular}{|c|c|c|c|c|c|}
\hline \multicolumn{2}{|c|}{ Code Number of Variables } & \multicolumn{4}{|c|}{ Numerical Characteristics } \\
\hline Variables & Remark & Mean & Stdev & Min & Max \\
\hline $\begin{array}{c}\text { Subjective sense of } \\
\text { happiness }\end{array}$ & $\begin{array}{c}\text { Very unhappy=1 } \\
\text { less happy=2 } \\
\text { not clearly=3 } \\
\text { happy=4 } \\
\text { very happy=5 }\end{array}$ & 3.866 & 0.818 & 1 & 5 \\
\hline $\begin{array}{l}\text { Household } \\
\text { registration }\end{array}$ & $\begin{array}{c}\text { Urban }=1 \\
\text { rural }=0\end{array}$ & 0.365 & 0.481 & 0 & 1 \\
\hline Medical insurance & $\begin{array}{c}\text { Participate }=1 \\
\text { not participate }=0\end{array}$ & 0.912 & 0.283 & 0 & 1 \\
\hline Pension insurance & $\begin{array}{c}\text { Participate }=1 \\
\text { not participate }=0\end{array}$ & 0.699 & 0.458 & 0 & 1 \\
\hline Gender & Male $=1$ female $=0$ & 0.468 & 0.499 & 0 & 1 \\
\hline Age & & 51.526 & 16.769 & 20 & 95 \\
\hline Agesq & Age $^{\wedge 2}$ & 2936.130 & 1765.129 & 400 & 9025 \\
\hline $\begin{array}{l}\text { Awareness of } \\
\text { income level }\end{array}$ & $\begin{array}{c}\text { far below average }=1 \\
\text { below average }=2 \\
\text { average }=3 \\
\text { above average }=4 \\
\text { far above average }=5\end{array}$ & 2.652 & 0.717 & 1 & 5 \\
\hline Health status & $\begin{array}{c}\text { Very unhealthy=1 } \\
\text { less healthy=2 } \\
\text { general=3 healthy=4 } \\
\text { very healthy=5 }\end{array}$ & 3.607 & 1.073 & 1 & 5 \\
\hline Education & $\begin{array}{c}\text { Primary school } \\
\text { and below }=1 \\
\text { Junior high school and } \\
\text { equivalent }=2 \\
\text { high school } \\
\text { and equivalent=3 } \\
\text { college and } \\
\text { equivalent }=4 \\
\text { Postgraduate } \\
\text { and above=5 }\end{array}$ & 2.581 & 0.943 & 1 & 5 \\
\hline Political status & $\begin{array}{l}\text { Communist }=1 \\
\text { non-party }=0\end{array}$ & 0.849 & 0.358 & 0 & 1 \\
\hline
\end{tabular}

\subsection{Empirical Analysis}

Table 4 illustrates the regression results of the happiness effect of the social security participation. Firstly, the impact of the selected control variables on subjective well-being is estimated in Module1.Secondly, the impact of the participating behaviours on the happiness is showed in the following models, which represent the nationwide sample, the rural sample, and the urban sample. (Module2, Module3, Module4).

Model1 shows the happiness effect of the control variables. The estimation results show that all control variables pass the significance test except the education. Women have higher happiness than men and the possible explanation is that males are under higher life stress than females. The relationship between age and happiness shows a U-shaped structure, which means that the subjective sense of happiness drops to its lowest point and then rise with the growth of the age. Awareness of income level has a significant positive effect on happiness and health status is positively related to happiness too. Party members are less happy than non-Party members. 
Table 4 Empirical results

\begin{tabular}{|c|c|c|c|c|}
\hline \multirow{2}{*}{ Variables } & \multicolumn{4}{|c|}{ Empirical Results } \\
\hline & Model1 & Model2 & Model3 & Model4 \\
\hline \multicolumn{5}{|l|}{$\begin{array}{c}\text { Control } \\
\text { Variables }\end{array}$} \\
\hline Male & $\begin{array}{c}-0.211 * * * \\
(0.039)\end{array}$ & $\begin{array}{c}-0.210 * * * \\
(0.039)\end{array}$ & $\begin{array}{c}0.196 * * * \\
(0.049)\end{array}$ & $\begin{array}{c}-0.241^{* * *} \\
(0.066)\end{array}$ \\
\hline Age & $\begin{array}{c}-0.021 * * \\
(0.007)\end{array}$ & $\begin{array}{c}-0.027 * * * \\
(0.007)\end{array}$ & $\begin{array}{c}-0.025^{* *} \\
(0.009)\end{array}$ & $\begin{array}{c}-0.031 * * \\
(0.011)\end{array}$ \\
\hline Agesq & $\begin{array}{c}0.000 * * * \\
(0.000)\end{array}$ & $\begin{array}{c}0.000 * * * \\
(0.000)\end{array}$ & $\begin{array}{c}0.000 * * * \\
(0.000)\end{array}$ & $\begin{array}{c}0.000^{* * *} \\
(0.000)\end{array}$ \\
\hline Awareness of income level & $\begin{array}{c}0.730 * * * \\
(0.029)\end{array}$ & $\begin{array}{c}0.718 * * * \\
(0.030)\end{array}$ & $\begin{array}{c}0.749 * * * \\
(0.037)\end{array}$ & $\begin{array}{c}0.677 * * * \\
(0.049)\end{array}$ \\
\hline Health status & $\begin{array}{c}0.428 * * * \\
(0.021)\end{array}$ & $\begin{array}{c}0.428 * * * \\
(0.021)\end{array}$ & $\begin{array}{c}0.408 * * * \\
(0.025)\end{array}$ & $\begin{array}{c}0.465^{* * * *} \\
(0.036)\end{array}$ \\
\hline Education & $\begin{array}{c}0.039 \\
(0.023)\end{array}$ & $\begin{array}{c}0.033 \\
(0.023) \\
\end{array}$ & $\begin{array}{c}0.034 \\
(0.030)\end{array}$ & $\begin{array}{c}0.054 \\
(0.041) \\
\end{array}$ \\
\hline Political status & $\begin{array}{c}-0.285 * * * \\
(0.059)\end{array}$ & $\begin{array}{c}-0.277 * * * \\
(0.059)\end{array}$ & $\begin{array}{c}-0.236^{* *} \\
(0.087)\end{array}$ & $\begin{array}{c}-0.328^{* * *} \\
(0.081)\end{array}$ \\
\hline \multicolumn{5}{|l|}{ Independent Variables } \\
\hline $\begin{array}{c}\text { Only involved in medical } \\
\text { insurance }\end{array}$ & & $\begin{array}{l}0.228 * * \\
(0.084)\end{array}$ & $\begin{array}{c}0.201 \\
(0.104) \\
\end{array}$ & $\begin{array}{c}0.290 \\
(0.148)\end{array}$ \\
\hline $\begin{array}{c}\text { Only involved in pension } \\
\text { insurance }\end{array}$ & & $\begin{array}{c}0.083 \\
(0.159) \\
\end{array}$ & $\begin{array}{c}0.102 \\
(0.194)\end{array}$ & $\begin{array}{c}0.001 \\
(0.277)\end{array}$ \\
\hline $\begin{array}{l}\text { Participate in two social } \\
\text { insurance programs }\end{array}$ & & $\begin{array}{c}0.329 * * * \\
(0.079)\end{array}$ & $\begin{array}{c}0.338 * * * \\
(0.099)\end{array}$ & $\begin{array}{l}0.306^{*} \\
(0.132)\end{array}$ \\
\hline $\mathrm{R}^{2}$ & 0.0625 & 0.0634 & 0.0615 & 0.0648 \\
\hline $\mathrm{N}$ & 10632 & 10632 & 6747 & 3885 \\
\hline
\end{tabular}

Notes: Standard errors in parentheses, ${ }^{*} p<0.05,{ }^{* *} p<0.01,{ }^{* * *} p<0.001$.

The regression result of model 2 provides the information of the happiness effect on the total sample. The estimation results show that citizens who enjoy the two basic social insurance programs have positive effect to the happiness and pass the significance test of $0.1 \%$, thus the hypothesis1 is confirmed. Also, people who only involved in medical insurance pass the significance test while the variable that only involved in pension insurance fails to pass. It may be for the reason that the coverage rate of the former is greater than that of the latter so the people who is enjoying the benefits of medical insurance is larger than those who benefit from pension insurance. Also, aging is the natural course of life and it can be viewed objectively while the health status is important in the whole life stage and people attach more importance to it. The participation of the two social insurance programs has the obvious effect on improving the happiness of residents and it can be roughly 1.4 times than people who do not attend any social insurance program.

In the comparison of regression model3 and model4, it can be seen that the happiness effects on rural households is greater than that of urban households. Under the influence of historical factors, the urban social security system is relatively more robust and higher quantity of urban citizens are involved in the safety net and they have greater awareness of social security. In contrast, the income of rural residents is less stable and there are more disadvantaged groups. Therefore, the impact of social security on residents of rural households is greater than that of urban households and the hypothesis 2 is verified.

Also, the relationship between pension insurance and residents' happiness is not significant. This may be for the reason that the urban households enjoy a higher income level before retirement and the relationship of pension and happiness is not significant for pension is only a way to protect their lives. As for the rural residents, the pension is necessary to maintain their life and the participation thus plays an important role as necessity so it does not have a significant effect on their happiness. 


\section{Conclusions and Inspirations}

This study reached the following conclusions after the empirical analysis:

First, social security system has a significant positive impact on residents' subjective sense of happiness. As a means of redistribution of national income, the fair effect of the social security system will lead to the fairness perception of the public, which will in turn affect the perception of happiness of the citizens. Also, social security system has promoted the social stability and economic growth and provide direct economic support to the residents, thus citizens will have faith to grasp the risks that are unpredictable.

Second, the happiness effect of social security has difference in urban-rural household registration and it is also affected by other characteristics like gender, age, health and so on. In the analysis of household registration, empirical study has found that the impact of social security participation on happiness of rural residents is greater than that of residents of urban households. This shows that the need of social security is even stronger for residents of rural areas. This is mainly due to the fact that there is still a certain degree of disparity in income and living standard among rural and urban residents.

Third, the medical insurance has a significant positive impact on subjective sense of happiness and the pension insurance does not. The impact of the medical insurance is remarkable because the scope of the medical insurance participation is larger, and the citizens' emphasis on health and the effectiveness of medical insurance are relatively stronger. For the pension insurance, elderly is the mainly targeted group and the participation rate is lower. Therefore, the relationship between the pension insurance and the residents' subjective sense of happiness is not significant.

Based on the above conclusions, the following inspirations to continuously improve the happiness of urban and rural residents can be proposed:

First, optimize the overall design of social security system, complete the project of social security system, strengthen the integration of the system, and achieve sustainable development. The design of the social security system and the improvement of the project should be matched with the diversified needs of the residents' lives and gradually rise to guarantee the spiritual level of the residents.

Second, reduce the gap between different groups and increase the coverage of social security benefits. Increasing the social equity and extending the coverage of the social security system.

Third, gradually realize the integration of the key insurance project like the medical insurance in urban and rural areas. The integration can reduce the incidence of poverty due to illness and also the chance of returning to poverty due to illness of rural households, and only the rural residents can truly afford the disease can they enhance their sense of happiness and life satisfaction.

\section{References}

[1] Ed;Martin E.P. Beyond Money:Toward an Economy of Well-being.Psychological Science in the Public Interest.P1-30,May 2004.

[2] Easterlin R. Does Economic Growth Improve the Human Lot? Some Empirical Evidence [C]//P. A, David, M. W. Reder .Nations and Households in Economic Growth. New York: Academic Press.P199, Feb.1974.

[3] Paul Dolan, Tessa Peasgood, Mathew White. Do we really know what makes us happy? A review of the economic literature on the factors associated with subjective well-being. Journal of Economic Psychology, P94-122, Jan.2008.

[4] Veenhoven, R: Well-being in the welfare state: Level not higher, distribution not more equitable, Journal of Comparative Policy Analysis: Research and Practice, P91, Feb.2000.

[5] Shiqing Jiang, Ming Lu, Huiroshi Sato, Identity and Happiness: Evidence from Urban China. [Z]Working Paper from School of Economics, Fudan University, 2010. 